systemie prawnym. Określił je jako liberty right i claim right (procedury, które można świadczyć pacjentowi i procedury, które koniecznie trzeba mu świadczyć). Kończąc swoje wystąpienie wyraził pogląd, że klauzula sumienia jest jednym z podstawowych praw pracowników służby zdrowia. Drugi z prelegentów, powołując się na przysięgę Hipokratesa, przyrzeczenie lekarskie i Kodeks Etyki Lekarskiej stwierdził, że lekarz nie może działać w sprzeczności ze swoim powołaniem, czyli ratowaniem życia i zdrowia pacjenta.

Druga część konferencji dotyczyła prezentacji Stanowiska Zespołu Ekspertów Konferencji Episkopatu Polski ds. Bioetycznych z dnia 14 lutego 2014 r. w sprawie klauzuli sumienia. Głos zabrali w kolejności: abp Henryk Hoser, prof. Zbigniew Cieślak oraz dr Piotr Klimas. W swoich wystąpieniach prezentowali wyżej wspomniany dokument od strony jego treści i struktury. Wszyscy podkreślali jego ważność jako głos Kościoła katolickiego w odpowiedzi na stanowisko Komitetu Bioetyki przy Prezydium PAN. Podsumowaniem konferencji były pytania z sali i dyskusja. Całość Konferencji podsumował pan Marcin Przeciszewski dziękując prelegentom za twórcze wystąpienia, a wszystkim za liczny udział.

Ks. mgr lic. Michat Czelny Wydziat Prawa, Prawa Kanonicznego i Administracji Katolicki Uniwersytet Lubelski Jana Pawła II

Sympozjum naukowe pt. Prawo matżeńskie Kościotów chrześcijańskich w Polsce $w$ kontekście wyznaniowej formy matżeństwa cywilnego, Warszawa, 26 marca 2014 r.

W dniu 26 marca 2014 r. w Chrześcijańskiej Akademii Teologicznej w Warszawie odbyło się sympozjum naukowe pt. Prawo matżeńskie Kościołów chrześcijańskich $w$ Polsce $w$ kontekście wyznaniowej formy małżeństwa cywilnego. Organizatorem wydarzenia była Katedra Prawa Wyznaniowego i Kanonicznego ChAT, a honorowy patronat nad nim objęli Minister Administracji i Cyfryzacji oraz Minister Spraw Wewnętrznych. Zdaniem organizatorów, za potrzebą podjęcia przedmiotowej problematyki przemawiała stosunkowo słaba znajomość małżeńskiego prawa kanonicz- 
nego polskich Kościołów chrześcijańskich, których dotyczą przepisy o wyznaniowej formie zawarcia małżeństwa cywilnego. Właściwie poza regulacjami obowiązującymi w Kościele katolickim, normy dotyczące małżeństwa w prawie wewnętrznym innych Kościołów chrześcijańskich nie były jeszcze przedmiotem badań naukowych na gruncie polskiego prawa wyznaniowego. W trakcie Sympozjum przedstawione zostały zatem regulacje obowiązujące $\mathrm{w}$ dziesięciu Kościołach posiadających prawo stosowania wyznaniowej formy małżeństwa cywilnego. Szczególną uwagę poświęcono zwłaszcza regulacjom odznaczającym się szczególną doniosłością dla tej formy zawarcia małżeństwa.

Sympozjum otworzył ks. prof. dr hab. Bogusław Milerski - Rektor ChAT, wspólnie z panem Ministrem Stanisławem Huskowskim - sekretarzem stanu w Ministerstwie Administracji i Cyfryzacji, panem Ministrem Rafałem Magrysiem - podsekretarzem stanu w Ministerstwie Spraw Wewnętrznych oraz ks. bp. prof. zw. dr. hab. Wiktorem Wysoczańskim, zwierzchnikiem Kościoła Polskokatolickiego w RP i kuratorem Katedry Prawa Wyznaniowego i Kanonicznego ChAT. Obrady podzielone zostały na trzy sesje, w trakcie których prelegenci przedstawili prawo małżeńskie poszczególnych Kościołów. Jako pierwszy wystąpił ks. prof. zw. dr hab. Artur Mezglewski (UO), który przybliżył uregulowania Kościoła katolickiego. Następnie ks. prof. nadzw. dr Jerzy Tofiluk (ChAT), omówił prawo małżeńskie Polskiego Autokefalicznego Kościoła Prawosławnego, dr Michał Hucał (ChAT) - Kościoła Ewangelicko-Augsburskiego, a z kolei ks. bp Zdzisław Tranda, emerytowany zwierzchnik Kościoła Ewangelicko-Reformowanego, przedstawił prawo małżeńskie tego Kościoła. Ks. superintendent Adam Kleszczyński scharakteryzował prawo małżeńskie Kościoła Ewangelicko-Metodystycznego, mgr Dawid Breuer - Kościoła Chrześcijan Baptystów, ks. mgr Andrzej Siciński (WST-H w Podkowie Leśnej) - Kościoła Adwentystów Dnia Siódmego, ks. dr Tadeusz Urban - Kościoła Polskokatolickiego, ks. dr Tomasz Mames - Kościoła Starokatolickiego Mariawitów, a ks. bp dr Marek Kamiński - Kościoła Zielonoświątkowego. Zwieńczeniem były dwa wystąpienia ukazujące szerszą problematykę natury prawnej. Ks. prof. zw. dr hab. Ginter Dzierżon (UKSW), wygłosił referat pt. Realizacja warunków dotyczacych nupturientów $w$ przypadku zawierania matżeństwa przez katolika z wiernym Kościoła lub Wspólnoty nie mającej petnej łaczności z Kościołem katolickim (kan. 1125, n. 1-3 KPK). Na zakończenie prof. nadzw. dr hab. Tadeusz J. Zieliński (ChAT) przedstawił problematykę pt. Materie z zakresu 
wyznaniowej formy malżeństwa cywilnego wymagające regulacji prawa kościelnego.

Udział w Sympozjum wzięli przedstawiciele środowiska naukowego, akademickiego i kościelnego. Przybyli hierarchowie Kościołów, których prawo małżeńskie było prezentowane. Obecne było także liczne grono pracowników administracji publicznej, w tym urzędów stanu cywilnego, adwokatów, teologów i religioznawców, a także studentów i doktorantów prawa oraz teologii. Prezentacja porządku prawnego Kościołów chrześcijańskich $\mathrm{w}$ aspekcie małżeńskim stała się okazją nie tylko do poznania różnorodnych ujęć małżeństwa w odnośnych wspólnotach oraz reżimów prawnych z tego zakresu, ale - jak pokazała to także ożywiona dyskusja - stanowiła inspirację dla prawodawców w poszczególnych podmiotach konfesyjnych w zakresie optymalizacji przyjętych uregulowań. Sympozjum stworzyło także możliwość zgłoszenia wniosków de lege ferenda dotyczących prawa polskiego z zakresu formy wyznaniowej małżeństwa cywilnego. $Z$ wielkim zainteresowaniem oczekiwana jest zatem publikacja wygłoszonych w trakcie Sympozjum referatów i głosów w dyskusji.

dr Marta Ordon Wydział Prawa, Prawa Kanonicznego i Administracji Katolicki Uniwersytet Lubelski Jana Pawła II

\section{Ogólnopolskie Sympozjum Prawa Wyznaniowego pt. Aktualne problemy wolności myśli, sumienia $i$ wyznania, Lublin, 15-17 maja 2014 r.}

W dniach 15-17 maja 2014 r. w Lublinie odbyło się XI Ogólnopolskie Sympozjum Prawa Wyznaniowego pt. Aktualne problemy wolności myśli, sumienia $i$ wyznania połączone ze Zjazdem Katedr, Zakładów i Wykładowców Prawa Wyznaniowego. Organizatorem sympozjum była Katedra Prawa Wyznaniowego Katolickiego Uniwersytetu Lubelskiego Jana Pawła II oraz Polskie Towarzystwo Prawa Wyznaniowego, a honorowy patronat nad nim objął Minister Administracji i Cyfryzacji - pan Rafał Trzaskowski. O wyborze tematyki Sympozjum zadecydowała jej aktualność, a także przypadająca w tych dniach 25 . rocznica uchwalenia przełomowej ustawy 